
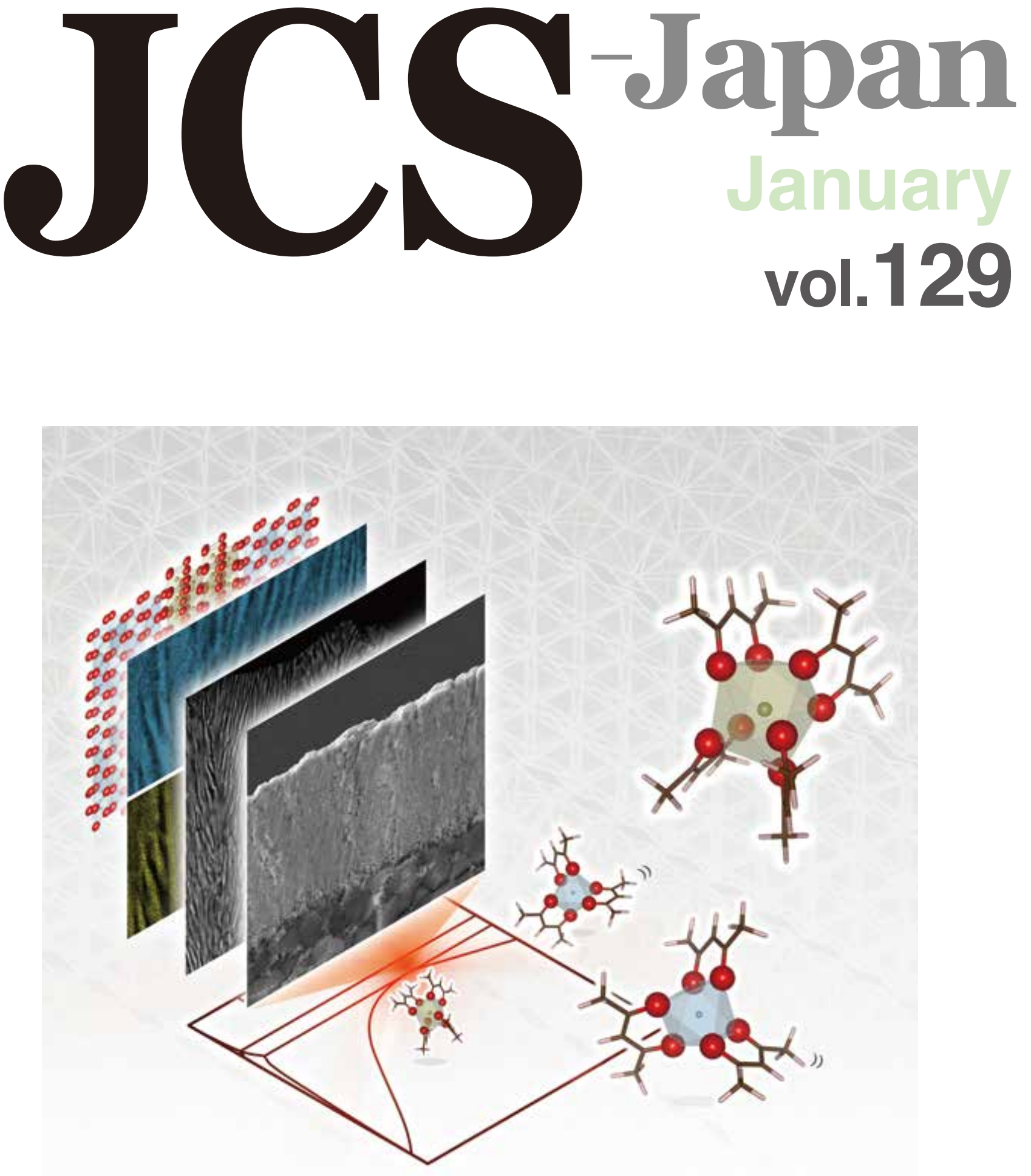

Journal of the Ceramic Society of Japan 


\title{
Preparation of $\mathrm{HfO}_{2}-\mathrm{Al}_{2} \mathrm{O}_{3}$ nanocomposite films using chemical vapor deposition
}

\author{
Shogen MATSUMOTO ${ }^{1}$ and Akihiko ITO ${ }^{1, \dagger}$ \\ ${ }^{1}$ Graduate School of Environment and Information Sciences, Yokohama National University, \\ 79-7 Tokiwadai, Hodogaya-ku, Yokohama 240-8501, Japan
}

We prepared $\mathrm{HfO}_{2}-\mathrm{Al}_{2} \mathrm{O}_{3}$ nanocomposite films using chemical vapor deposition. Fibrous and lamellar microstructures formed in the monoclinic and tetragonal $\mathrm{HfO}_{2}\left(m / t-\mathrm{HfO}_{2}\right)-\alpha-\mathrm{Al}_{2} \mathrm{O}_{3}$ films at deposition temperature of $1573 \mathrm{~K}$ and $\mathrm{Al}$ mole fraction in the precursor vapor of $36-74 \mathrm{~mol} \% \mathrm{Al}_{2} \mathrm{O}_{3}$. Characterization by electron microscopy revealed that the $m / t-\mathrm{HfO}_{2}$ fibrous and lamellar structures are present throughout the $\alpha-\mathrm{Al}_{2} \mathrm{O}_{3}$ columnar matrix above $50 \mathrm{~mol} \% \mathrm{Al}_{2} \mathrm{O}_{3}\left(55 \mathrm{vol} \% \mathrm{Al}_{2} \mathrm{O}_{3}\right)$, while $\alpha-\mathrm{Al}_{2} \mathrm{O}_{3}$ lamellar structure was formed in $m$ $\mathrm{HfO}_{2}$ matrix below 50 mol \% $\mathrm{Al}_{2} \mathrm{O}_{3}$.

(O)2021 The Ceramic Society of Japan. All rights reserved.

Key-words : $\mathrm{HfO}_{2}, \mathrm{Al}_{2} \mathrm{O}_{3}$, Chemical vapor deposition, Nanocomposite, Eutectics

[Received July 13, 2020; Accepted September 29, 2020]

\section{Introduction}

Zirconia $\left(\mathrm{ZrO}_{2}\right)$ is widely used in structural ceramics and thermal barrier coatings due to its low thermal conductivity $\left(1.5-3.0 \mathrm{~W} \mathrm{~m}^{-1} \mathrm{~K}^{-1}\right)$ and high fracture toughness $\left(2-14 \mathrm{MPam}^{0.5}\right){ }^{1), 2)}$ The mechanical properties of $\mathrm{ZrO}_{2}$ can be enhanced by synthesizing composites with alumina $\left(\alpha-\mathrm{Al}_{2} \mathrm{O}_{3}\right)$, namely zirconia-toughened alumina ${ }^{3)-6)}$ or the $\mathrm{ZrO}_{2}-\mathrm{Al}_{2} \mathrm{O}_{3}$ eutectic. ${ }^{7-11)}$ These composites have been widely studied in the form of bulk samples prepared using sintering and melt-solidification techniques.

Hafnia $\left(\mathrm{HfO}_{2}\right)$ has similar properties and crystallographic features as $\mathrm{ZrO}_{2}$. Because $\mathrm{HfO}_{2}$ has a higher melting point $(3100 \mathrm{~K})$ and higher monoclinic-tetragonal transition point $(2200 \mathrm{~K})$ than $\left.\mathrm{ZrO}_{2},{ }^{12}\right) \mathrm{HfO}_{2}$-based ceramics are candidate materials for environmental barrier coatings. ${ }^{13), 14)}$ In addition to $\mathrm{HfO}_{2}$-based ceramics, $\mathrm{HfO}_{2}-$ $\mathrm{Al}_{2} \mathrm{O}_{3}$ eutectic composites have also been prepared using melt-solidification methods such as floating zone method $^{15)}$ and micro-pulling-down technique. ${ }^{16)}$

To make use of the excellent mechanical and thermal properties of $\mathrm{ZrO}_{2}-\mathrm{Al}_{2} \mathrm{O}_{3}$ and $\mathrm{HfO}_{2}-\mathrm{Al}_{2} \mathrm{O}_{3}$ composites in the form of coatings, a feasible deposition technique must be established. We have previously reported on chemical vapor deposition (CVD) of $\mathrm{ZrO}_{2}-\mathrm{Al}_{2} \mathrm{O}_{3}$ nanocomposite films, which exhibited high hardness and high thermal insulating properties. ${ }^{17)}$ In addition, $\mathrm{HfO}_{2}$ films exhibited self-

$\dagger$ Corresponding author: A. Ito; E-mail: ito-akihiko-xr@ynu. ac.jp

¥ Preface for this article: Dol http://doi.org/10.2109/jcersj2. 129.P1-1 oriented growth, and transparent $\mathrm{HfO}_{2}$ thick films can be obtained by a high-speed epitaxial growth technique. ${ }^{18), 19)}$

In the present study, we demonstrated CVD of $\mathrm{HfO}_{2}-$ $\mathrm{Al}_{2} \mathrm{O}_{3}$ nanocomposite films, we characterized the effects of deposition conditions on phase, and the microstructure of the films was investigated. Results for several temperaturecomposition combinations were plotted to create a CVD phase diagram for this system.

\section{Experimental procedure}

A schematic of the CVD apparatus has been described elsewhere. $^{20)}$ Metal-organic compounds of $\mathrm{Hf}(\mathrm{acac})_{4}$ (acac: acetylacetonate) (Mitsuwa Chemicals Co., Ltd.) and $\mathrm{Al}(\mathrm{acac})_{3}$ (Sigma-Aldrich Co. LLC) were maintained at temperatures of $443-473$ and $433-483 \mathrm{~K}$, respectively, in the precursor furnaces. Emitted precursor vapor was transferred to the deposition chamber using Ar as a carrier gas. $\mathrm{O}_{2}$ gas was introduced separately into the chamber through a double-tube nozzle. Total chamber pressure was maintained at $200 \mathrm{~Pa}$. The $\mathrm{Al}$ mole fraction in the precursor vapor $\left(C_{\mathrm{Al}_{2} \mathrm{O}_{3}}\right)$ was calculated from the mass change of each precursor during the course of a run, expressed in terms of an oxide $\left(\mathrm{mol} \% \mathrm{Al}_{2} \mathrm{O}_{3}\right)$ for the competitivity with equilibrium phase diagrams. Stoichiometry was controlled by varying the vaporization temperatures of the precursor sources.

A polycrystalline AlN plate $(8 \mathrm{~mm} \times 8 \mathrm{~mm} \times 1 \mathrm{~mm})$ was used as a substrate. A continuous-wave diode laser (wavelength: $\lambda=976 \mathrm{~nm}$; output power: $50-170 \mathrm{~W}$; Lumics $\mathrm{GmbH}, \mathrm{LU} 0976 \mathrm{C} 170)$ was used to irradiate the substrate through a fused quartz window, heating it to temperatures from 943 to $1573 \mathrm{~K}$. The deposition temperature $\left(T_{\text {dep }}\right)$ was 
measured using an optical pyrometer. Depositions were run for $0.6 \mathrm{ks}$.

The phase composition of the resultant films was determined by X-ray diffraction (XRD; Bruker D2 Phaser) using $\mathrm{CuK} \alpha$ radiation, generated at $30 \mathrm{kV}$ and $10 \mathrm{~mA}$. Backscattered electron (BSE) imaging of cross-sectional and surface microstructures was performed using a fieldemission scanning electron microscope (FE-SEM; Hitachi SU8010) operated $15 \mathrm{keV}$. An energy dispersive X-ray spectrometer integrated with the SEM (SEM-EDX; JEOL JSM-6510LA) and operated at an accelerating voltage of $20 \mathrm{kV}$ was used to determine composition of the films. SEM-EDX analysis was performed at 10 separate points on the surface of each film. The cross-sectional microstructure was observed using a transmission electron microscope (TEM; FEI Titan 80-300) equipped with an image corrector and a high-angle annular dark-field (HAADF) detector and operated at $300 \mathrm{keV}$. The lamella for TEM analysis was prepared using a focused ion beam system (FEI Versa 3D Dual Beam).

The volume fraction $\left(V_{t}\right)$ of the tetragonal $\mathrm{HfO}_{2}$ phase $\left(t-\mathrm{HfO}_{2}\right)$ to the monoclinic $\mathrm{HfO}_{2}\left(m-\mathrm{HfO}_{2}\right)$ phase was estimated using the following formulas: ${ }^{21), 22)}$

$$
\begin{aligned}
x_{t} & =\frac{I_{t}(101)}{I_{m}(11 \overline{1})+I_{m}(111)} \\
V_{t} & =\frac{x_{t}}{1.311-0.311 x_{t}}
\end{aligned}
$$

where $I_{\mathrm{t}}(h k l)$ and $I_{\mathrm{m}}(h k l)$ are the integrated intensites of the $h k l$ peaks for the $t-\mathrm{HfO}_{2}$ and $m-\mathrm{HfO}_{2}$ phases in the XRD patterns, respectively. The crystalline size $\left(D_{t}\right)$ of the $t$ $\mathrm{HfO}_{2}$ phase was estimated using the Scherrer equation:

$$
D_{t}=\frac{K \lambda}{B \cos \theta}
$$

where $K, \lambda, B, \theta$ are the Scherrer constant (0.9), the X-ray wavelength $(0.154 \mathrm{~nm})$, the full width at half maximum of the peak, and the Bragg angle, respectively, of the $t-\mathrm{HfO}_{2}$ 101 peak. The apparent volume fraction of $\mathrm{Al}_{2} \mathrm{O}_{3}$ in the film $\left(V_{\mathrm{Al}_{2} \mathrm{O}_{3}}\right)$ was calculated as the theoretical volume fraction of the $\alpha-\mathrm{Al}_{2} \mathrm{O}_{3}$ phase to that of the $m-\mathrm{HfO}_{2}$ by assuming $m$ - $\mathrm{HfO}_{2}-\alpha-\mathrm{Al}_{2} \mathrm{O}_{3}$ pseudo-binary composite films for the sake of simplicity.

\section{Results and discussion}

\subsection{Phase composition of $\mathrm{HfO}_{2}-\mathrm{Al}_{2} \mathrm{O}_{3}$ films}

Figure 1 shows the relationship between $\mathrm{Al}$ mole fraction in the vapor versus that in the film for deposition temperatures of 1323 and $1573 \mathrm{~K}$. The $\mathrm{Al}$ mole fraction in the film increased linearly with the increase of that in the vapor, indicating that the $\mathrm{Al}$ mole fraction in the film can be directly controlled by varying the vaporization temperatures of each precursor, regardless of the deposition temperature.

Monolithic $m-\mathrm{HfO}_{2}$ and $\alpha-\mathrm{Al}_{2} \mathrm{O}_{3}$ films were obtained at both ends of the compositional space $(0$ and 100 mol $\% \mathrm{Al}_{2} \mathrm{O}_{3}$, respectively). At deposition temperatures of 1573 and $1373 \mathrm{~K}, m-\mathrm{HfO}_{2}-\alpha-\mathrm{Al}_{2} \mathrm{O}_{3}$ composite films

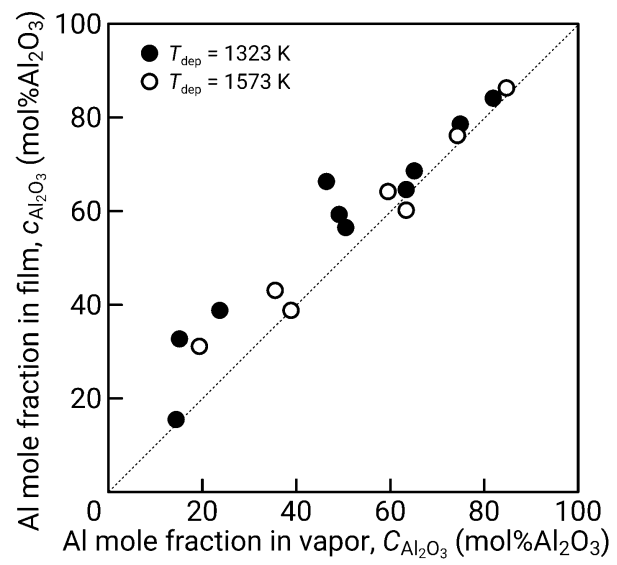

Fig. 1. Relationship between the $\mathrm{Al}$ mole fraction in the vapor $\left(C_{\mathrm{Al}_{2} \mathrm{O}_{3}}\right)$ and in the CVD film $\left(c_{\mathrm{Al}_{2} \mathrm{O}_{3}}\right)$.

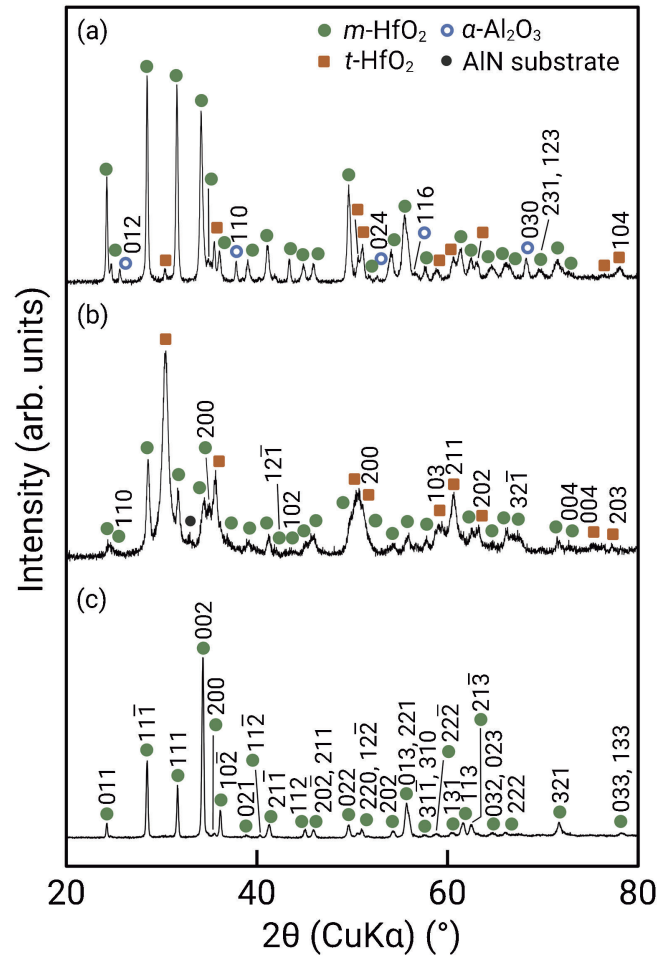

Fig. 2. XRD patterns of the $\mathrm{HfO}_{2}-\mathrm{Al}_{2} \mathrm{O}_{3}$ nanocomposite films prepared at various deposition temperatures and $\mathrm{Al}$ mole fractions in the vapor: (a) $1573 \mathrm{~K}$ and $60 \mathrm{~mol}_{\%} \mathrm{Al}_{2} \mathrm{O}_{3}$, (b) $1323 \mathrm{~K}$ and $63 \mathrm{~mol} \% \mathrm{Al}_{2} \mathrm{O}_{3}$, and (c) $1193 \mathrm{~K}$ and $64 \mathrm{~mol} \% \mathrm{Al}_{2} \mathrm{O}_{3}$.

resulted. Above $49 \mathrm{~mol} \% \mathrm{Al}_{2} \mathrm{O}_{3}$, the $t-\mathrm{HfO}_{2}$ phase was also present in the $m-\mathrm{HfO}_{2}-\alpha-\mathrm{Al}_{2} \mathrm{O}_{3}$ nanocomposite films [Fig. 2(a)]. At deposition temperatures of 1373 and $1173 \mathrm{~K}, \mathrm{XRD}$ patterns were indexed with a mixture of $t$ and $m-\mathrm{HfO}_{2}$ phases $\left(m / t-\mathrm{HfO}_{2}\right)$ and the $m-\mathrm{HfO}_{2}$ phase, respectively, with no $\mathrm{Al}_{2} \mathrm{O}_{3}$ peaks, suggesting that the $\mathrm{Al}_{2} \mathrm{O}_{3}$ phase was amorphous [Figs. 2(b) and 2(c)].

Figure 3 summarizes the relationship between the $\mathrm{Al}$ mole fraction in the vapor and the apparent $\mathrm{Al}_{2} \mathrm{O}_{3}$ volume fraction in the film, the calculated $m / t-\mathrm{HfO}_{2}$ volume fractions, and the $t-\mathrm{HfO}_{2}$ crystallite size in the films. At deposition temperatures of $1373-1573 \mathrm{~K}, \mathrm{HfO}_{2}$ exhibited a monoclinic phase below $40 \mathrm{~mol} \% \mathrm{Al}_{2} \mathrm{O}_{3}$, whereas $t-\mathrm{HfO}_{2}$ 


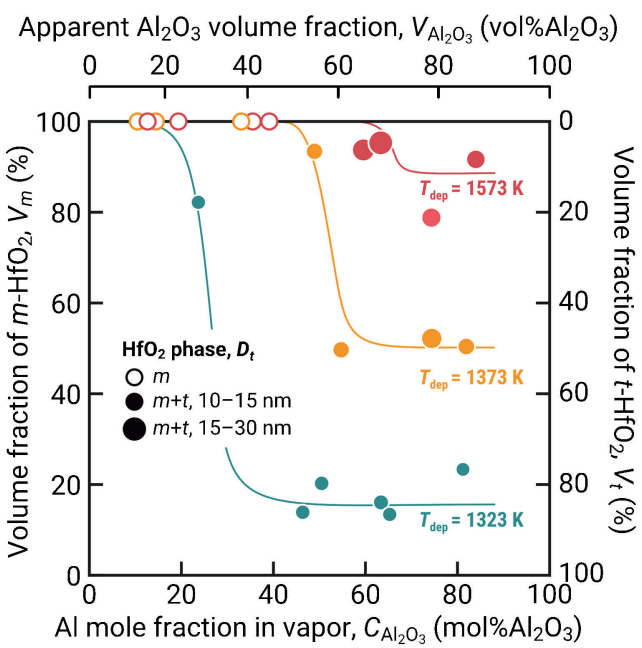

Fig. 3. Effect of the $\mathrm{Al}$ volume fraction in the vapor $\left(C_{\mathrm{Al}_{2} \mathrm{O}_{3}}\right)$ and the deposition temperature $\left(T_{\text {dep }}\right)$ on the $m$ - $\mathrm{HfO}_{2}$ volume fraction $\left(V_{m}\right)$ and the $t-\mathrm{HfO}_{2}$ grain size $\left(V_{t}\right)$ in the $\mathrm{HfO}_{2}-\mathrm{Al}_{2} \mathrm{O}_{3}$ nanocomposite films.
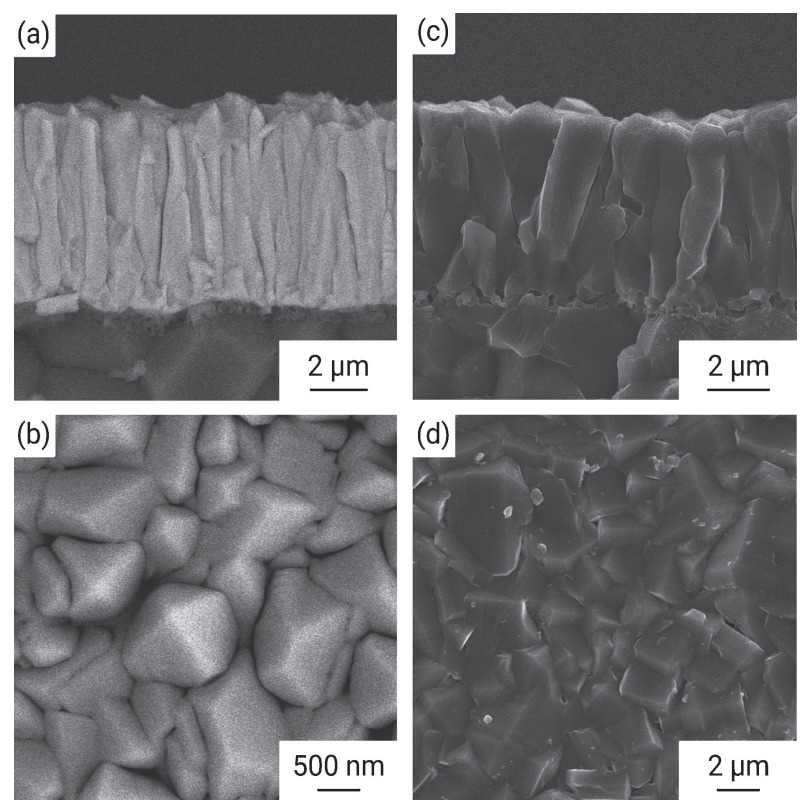

Fig. 4. (a, c) Cross-sectional and (b, d) surface BSE-SEM images of the $m-\mathrm{HfO}_{2}$ and $\alpha-\mathrm{Al}_{2} \mathrm{O}_{3}$ films prepared at $1573 \mathrm{~K}$.
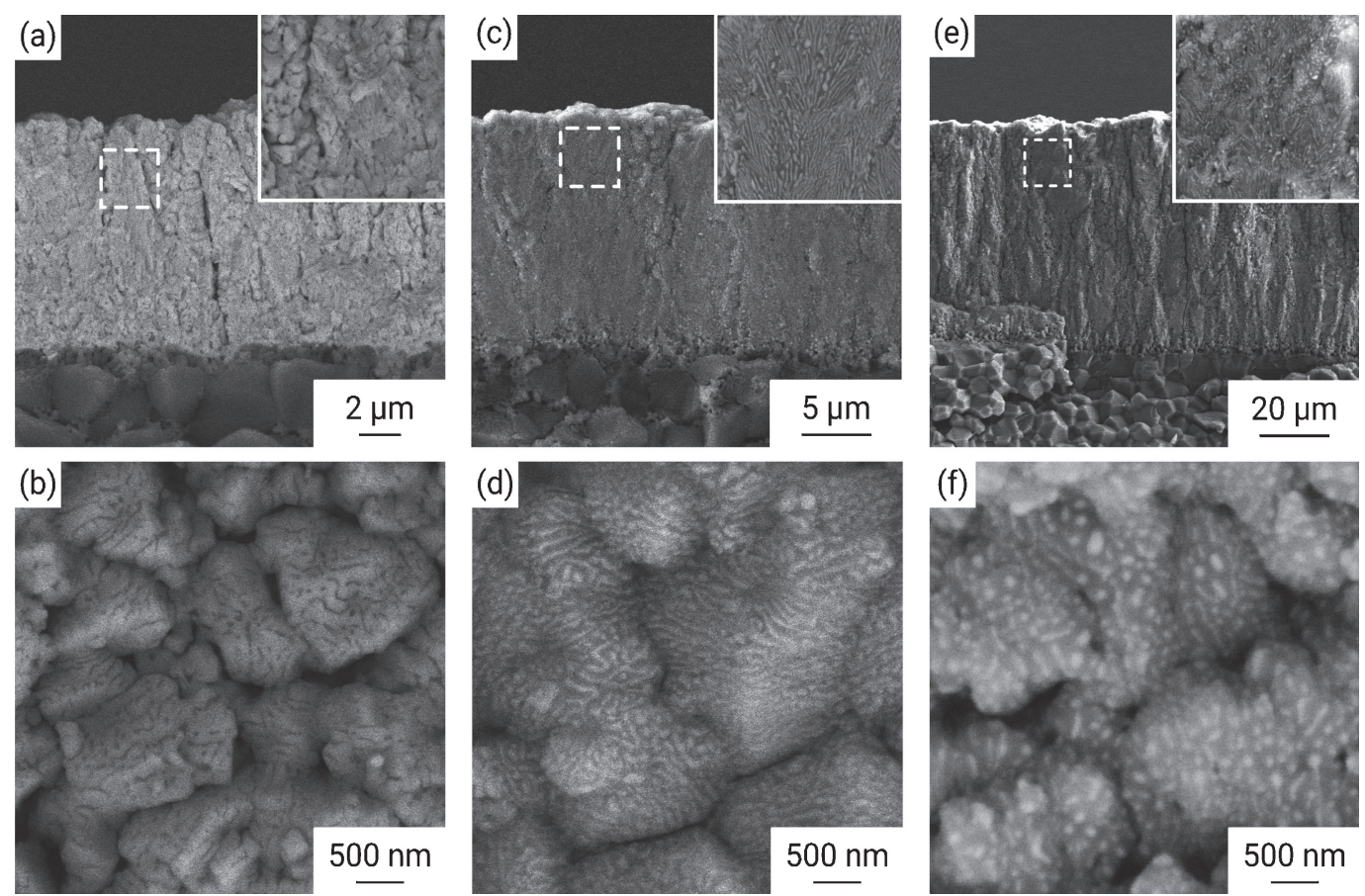

Fig. 5. (a, c, e) Cross-sectional and ( $b, d, f)$ surface BSE-SEM images of the $\mathrm{HfO}_{2}-\mathrm{Al}_{2} \mathrm{O}_{3}$ nanocomposite films prepared at $1573 \mathrm{~K}$ and various $\mathrm{Al}$ mole fractions in the vapor: (a, b) $36 \mathrm{~mol} \% \mathrm{Al}_{2} \mathrm{O}_{3}$, (c, d) $60 \mathrm{~mol} \% \mathrm{Al}_{2} \mathrm{O}_{3}$, and (e, f) $74 \mathrm{~mol} \% \mathrm{Al}_{2} \mathrm{O}_{3}$. The white and gray contrast correspond to the $\mathrm{HfO}_{2}$ and $\mathrm{Al}_{2} \mathrm{O}_{3}$ phases, respectively.

co-existed in the $m$ - $\mathrm{HfO}_{2}-\alpha-\mathrm{Al}_{2} \mathrm{O}_{3}$ films above 50 mol $\% \mathrm{Al}_{2} \mathrm{O}_{3}$. As the deposition temperature decreased from 1573 to $1323 \mathrm{~K}$, the $t$ - $\mathrm{HfO}_{2}$ volume fraction was increased from 5 to $87 \%$, with a decline in the $t-\mathrm{HfO}_{2}$ crystallite size from 36 to $12 \mathrm{~nm}$.

\subsection{Microstructure of $\mathrm{HfO}_{2}-\mathrm{Al}_{2} \mathrm{O}_{3}$ films}

Monolithic $m$ - $\mathrm{HfO}_{2}$ and $\alpha-\mathrm{Al}_{2} \mathrm{O}_{3}$ films exhibited columnar structures with pyramidal and polygonal surface facets
(Fig. 4). $\mathrm{HfO}_{2}-\mathrm{Al}_{2} \mathrm{O}_{3}$ films prepared at $1573 \mathrm{~K}$ and $36-74$ $\mathrm{mol} \% \mathrm{Al}_{2} \mathrm{O}_{3}$ showed fuzzy columnar structures in crosssections (Fig. 5). High-magnification BSE-SEM images and surface observations revealed fibrous and lamellar structures in the $\mathrm{HfO}_{2}-\mathrm{Al}_{2} \mathrm{O}_{3}$ films, with the light and dark contrast corresponding to $\mathrm{Hf}$ and Al. A lamellar $\alpha-\mathrm{Al}_{2} \mathrm{O}_{3}$ microstructure was formed in the $m-\mathrm{HfO}_{2}$ columnar matrix at $36 \mathrm{~mol} \% \mathrm{Al}_{2} \mathrm{O}_{3}$ [Figs. 5(a) and 5(b)], while fibrous and lamellar $m$ - $-\mathrm{HfO}_{2}$ microstructures grew inside the $\alpha-\mathrm{Al}_{2} \mathrm{O}_{3}$ 

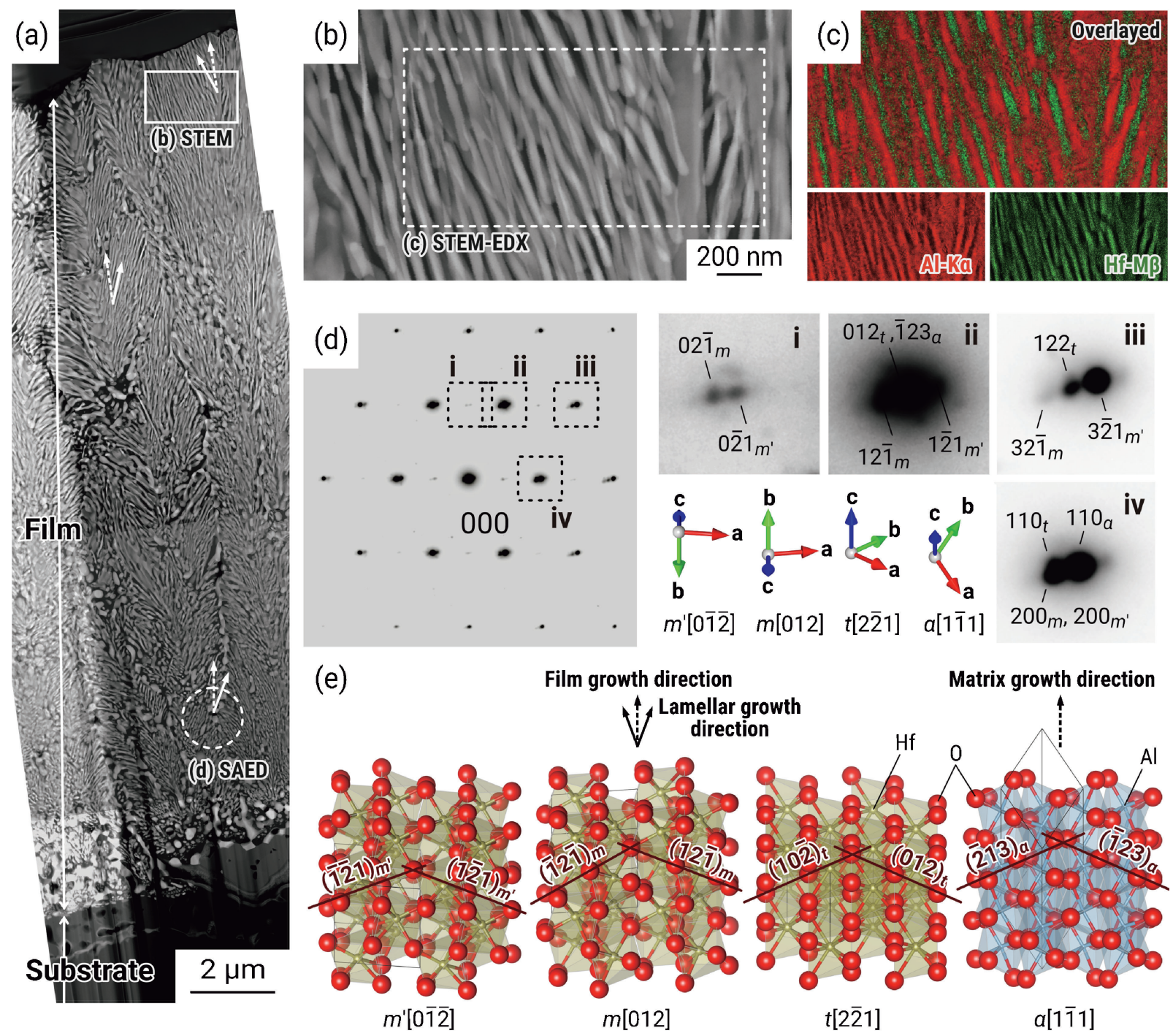

Fig. 6. (a) Cross-sectional HAADF-STEM image of the $m / t-\mathrm{HfO}_{2}-\alpha-\mathrm{Al}_{2} \mathrm{O}_{3}$ nanocomposite film prepared at $1573 \mathrm{~K}$ and $60 \mathrm{~mol} \% \mathrm{Al}_{2} \mathrm{O}_{3}$. (b) Highly magnified image of the rectangle region noted in (a), and (c) STEM-EDX elemental mapping of the intensity of the Al-K $\alpha$ and Hf-M $\beta$ lines. (d) SAED pattern of the circular region noted in (a), with enlarged regions of peaks of interest, marked by $\mathrm{i}-\mathrm{iv}$, along with axes indicating crystal orientation of the indexed phases. (e) Schematic illustrations of the crystal structures of the $m-\mathrm{HfO}_{2}$ viewed along the [01̄] and [012] zone axes, the $t-\mathrm{HfO}_{2}[2 \overline{2} 1]$, and $\alpha-\mathrm{Al}_{2} \mathrm{O}_{3}$ along [1 111$]$.

columnar matrix at 60 and $74 \mathrm{~mol} \% \mathrm{Al}_{2} \mathrm{O}_{3}$ [Figs. 5(c)5(f)]. Deposition rates of the $\mathrm{HfO}_{2}-\mathrm{Al}_{2} \mathrm{O}_{3}$ films prepared at $1573 \mathrm{~K}$ were $101-299 \mu \mathrm{m} \mathrm{h}^{-1}$.

TEM observation revealed that the fibrous and lamellar composite structures of $\mathrm{HfO}_{2}$ were developed throughout the entire columnar grains of the $\mathrm{Al}_{2} \mathrm{O}_{3}$ matrix [Figs. 6(a) and 6(b)]. Scanning TEM (STEM)-EDX characterization confirmed a monodirectional texture constituted of $\mathrm{HfO}_{2}$ and $\mathrm{Al}_{2} \mathrm{O}_{3}$ nanoscale grains [Fig. 6(c)]. No stabilizer element such as $\mathrm{Y}$ or $\mathrm{Ca}$ was identified in the EDX spectrum. The selected-area electron diffraction (SAED) pattern was indexed with zone axes of $m$ - $\mathrm{HfO}_{2}[0 \overline{1} \overline{2}], m-\mathrm{HfO}_{2}$ [012], $t$ $\mathrm{HfO}_{2}$ [22 1 ] , and $\alpha-\mathrm{Al}_{2} \mathrm{O}_{3}$ [11 11 , suggesting that the orientation relationship among $m-\mathrm{HfO}_{2}, t-\mathrm{HfO}_{2}$, and $\alpha-\mathrm{Al}_{2} \mathrm{O}_{3}$ is (100) $m$ - $\mathrm{HfO}_{2}\left\|(110) t-\mathrm{HfO}_{2}\right\|(110) \alpha-\mathrm{Al}_{2} \mathrm{O}_{3}$, as depicted in Fig. 6(d). The orientation relationship between the $m$ $\mathrm{HfO}_{2}$ and $t-\mathrm{HfO}_{2}$ phases was close to the crystallographic relationships between them, namely $(100)_{\mathrm{m}} \|(110)_{\mathrm{t}}$ and $(010)_{\mathrm{m}} \|(001)_{\mathrm{t}}{ }^{23)}$ Fig. 6(e) shows schematic illustrations of each phase projected along its corresponding zone axis. One of the close-packed planes of oxygen ions-i.e., the $m$ - $\mathrm{HfO}_{2}(100), t-\mathrm{HfO}_{2}(110)$, and $\alpha-\mathrm{Al}_{2} \mathrm{O}_{3}$ (110) planeswas parallel to the matrix growth direction, while the others, e.g., the $m$ - $\mathrm{HfO}_{2}\{121\}, t-\mathrm{HfO}_{2}\{012\}$, and $\alpha$ $\mathrm{Al}_{2} \mathrm{O}_{3}\{123\}$ planes, were perpendicular to the lamellar growth direction. The angles of lamellar growth directions from the film growth direction remained almost constant through the film thickness, as depicted in Fig. 6(a).

\subsection{Phase and microstructure of $\mathrm{HfO}_{2}-\mathrm{Al}_{2} \mathrm{O}_{3}$ films}

Figure 7 summarizes the effects of the $\mathrm{Al}$ mole fraction in the vapor and of the deposition temperature on the phase composition and microstructure of the $\mathrm{HfO}_{2}-\mathrm{Al}_{2} \mathrm{O}_{3}$ 


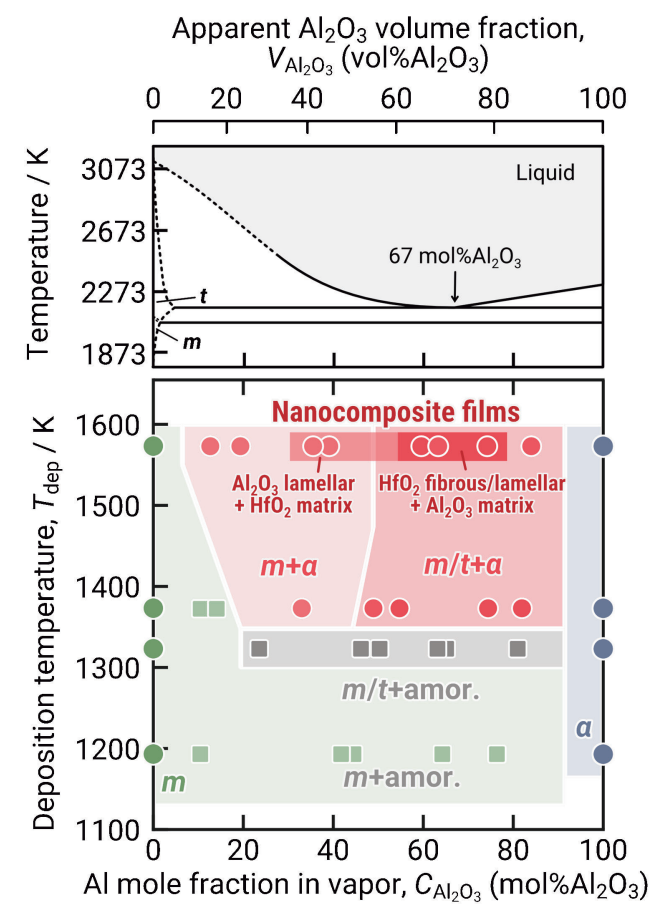

Fig. 7. (a) Equilibrium phase diagram of the $\mathrm{HfO}_{2}-\mathrm{Al}_{2} \mathrm{O}_{3}$ pseudo-binary system and (b) effects of the $\mathrm{Al}$ mole fraction in the vapor $\left(C_{\mathrm{Al}_{2} \mathrm{O}_{3}}\right)$ and the deposition temperature $\left(T_{\mathrm{dep}}\right)$ on the phase composition and microstructure of the $\mathrm{HfO}_{2}-\mathrm{Al}_{2} \mathrm{O}_{3}$ nanocomposite films. $\mathrm{m}$, $\mathrm{t}$, and $\alpha$ denote $m$ - $\mathrm{HfO}_{2}, t-\mathrm{HfO}_{2}$, and $\alpha-\mathrm{Al}_{2} \mathrm{O}_{3}$ phases, respectively.

nanocomposite films. The end-member $m-\mathrm{HfO}_{2}$ and $\alpha$ $\mathrm{Al}_{2} \mathrm{O}_{3}$ films (0 and $100 \mathrm{~mol} \% \mathrm{Al}_{2} \mathrm{O}_{3}$, respectively) exhibited a columnar structure. For films prepared below 50 mol \% $\mathrm{Al}_{2} \mathrm{O}_{3}\left(55 \mathrm{vol} \% \mathrm{Al}_{2} \mathrm{O}_{3}\right)$ and at deposition temperatures of 1373 and $1573 \mathrm{~K}$, the $t-\mathrm{HfO}_{2}$ grains co-existed with the $m-\mathrm{HfO}_{2}-\alpha-\mathrm{Al}_{2} \mathrm{O}_{3}$ films. In the film with an amorphous $\mathrm{Al}_{2} \mathrm{O}_{3}$ matrix deposited at $1373 \mathrm{~K}$, the $t-\mathrm{HfO}_{2}$ phase was stabilized.

In the $\mathrm{ZrO}_{2}-\mathrm{Al}_{2} \mathrm{O}_{3}$ system, Deb et al. reported that tetragonal $\mathrm{ZrO}_{2}$ stabilization by forming a $\mathrm{ZrO}_{2}-\mathrm{Al}_{2} \mathrm{O}_{3}$ solid solution was unlikely to take place because the ionic radius of $\mathrm{Al}^{3+}(0.068 \mathrm{~nm})$ is far smaller in comparison to that of $\mathrm{Zr}^{4+}(0.084 \mathrm{~nm}){ }^{24)}$ the case is believed to be the same for the $\mathrm{HfO}_{2}-\mathrm{Al}_{2} \mathrm{O}_{3}$ system $\left(\mathrm{Hf}^{4+}: 0.083 \mathrm{~nm}\right)$. On the other hand, stabilization of the tetragonal phase over the monoclinic one in nanocrystalline grains with no additives has been reported for both $\mathrm{ZrO}_{2}{ }^{24), 25)}$ and $\mathrm{HfO}_{2}{ }^{27)}$,28) Although the critical crystalline size of $\mathrm{HfO}_{2}$ might be smaller than that of $\mathrm{ZrO}_{2}(30 \mathrm{~nm})$ due to its higher melting point and smaller volume change at the monoclinictetragonal transition, the suppression of grain growth of $\mathrm{HfO}_{2}$ nuclei by surrounding them with an $\mathrm{Al}_{2} \mathrm{O}_{3}$ matrix could contribute to the stabilization of the tetragonal phase at room temperature.

$m-\mathrm{HfO}_{2}-\alpha-\mathrm{Al}_{2} \mathrm{O}_{3}$ and $m / t-\mathrm{HfO}_{2}-\alpha-\mathrm{Al}_{2} \mathrm{O}_{3}$ nanocomposite films were prepared at $1573 \mathrm{~K}$ and $36-74 \mathrm{~mol} \% \mathrm{Al}_{2} \mathrm{O}_{3}$. Fibrous microstructures of the $m / t-\mathrm{HfO}_{2}$ dispersoids and the $\alpha-\mathrm{Al}_{2} \mathrm{O}_{3}$ matrix were observed at $59-74 \mathrm{~mol} \% \mathrm{Al}_{2} \mathrm{O}_{3}$, which are near the eutectic composition of the $\mathrm{HfO}_{2}-$
$\mathrm{Al}_{2} \mathrm{O}_{3}$ pseudo-binary system $\left(67 \mathrm{~mol} \% \mathrm{Al}_{2} \mathrm{O}_{3}\right)$. No melt formation was observed by SEM and TEM characterizations because the deposition temperature of $1573 \mathrm{~K}$ was lower than the eutectic temperature of the $\mathrm{HfO}_{2}-\mathrm{Al}_{2} \mathrm{O}_{3}$ system $(2163 \mathrm{~K})$.

\section{Conclusions}

The $m-\mathrm{HfO}_{2}-\alpha-\mathrm{Al}_{2} \mathrm{O}_{3}$ and $m / t-\mathrm{HfO}_{2}-\alpha-\mathrm{Al}_{2} \mathrm{O}_{3}$ nanocomposite films were obtained at deposition temperatures of $1373-1573 \mathrm{~K}$. The $t-\mathrm{HfO}_{2}$ phase was also observed to be stabilized in an amorphous $\mathrm{Al}_{2} \mathrm{O}_{3}$ matrix for growth at $1323 \mathrm{~K}$ due to the suppression of $\mathrm{HfO}_{2}$ grain growth by the surrounding matrix.

We observed that the $m-\mathrm{HfO}_{2}-\alpha-\mathrm{Al}_{2} \mathrm{O}_{3}$ and $m / t-\mathrm{HfO}_{2}-$ $\alpha-\mathrm{Al}_{2} \mathrm{O}_{3}$ nanocomposite films with fibrous and lamellar grain structures at $1573 \mathrm{~K}$ and $36-74 \mathrm{~mol}_{\%} \mathrm{Al}_{2} \mathrm{O}_{3}$. Crosssectional TEM characterization of the films prepared at $60 \mathrm{~mol}_{\%} \mathrm{Al}_{2} \mathrm{O}_{3}$ revealed that the fibrous and lamellar $\mathrm{m} / \mathrm{t}$ $\mathrm{HfO}_{2}$ dispersoids are present through the full thickness of the $\alpha-\mathrm{Al}_{2} \mathrm{O}_{3}$ columnar grains of the matrix. Because these nanocomposite films were formed around the eutectic composition of the $\mathrm{HfO}_{2}-\mathrm{Al}_{2} \mathrm{O}_{3}$ pseudo-binary system (67 $\mathrm{mol} \% \mathrm{Al}_{2} \mathrm{O}_{3}$ ), the formation of fibrous and lamellar structures is associated with the eutectic nature of the system.

Acknowledgments This study was supported in part by the Japan Society for the Promotion of Sciences (JSPS) KAKENHI Grant Numbers JP17H03426, JP17H01319, JP20H02477, and JP20H05186. This study was also supported in part by Center for Integrated NanoTechnology Support, Tohoku University, Japan as a program of "Nanotechnology Platform" of MEXT, Japan. The authors would like to thank Drs. M. Nishijima and Y. Kodama for timely help in the TEM observation. FE-SEM observation (SU8010) and SEM-EDX analysis (JSM-6510LA) were carried out at Instrumental Analysis Center, Yokohama National University, Japan.

\section{References}

1) K. W. Schlichting, N. P. Padture and P. G. Klemens, J. Mater. Sci., 36, 3003-3010 (2001).

2) P. F. Becher and M. V. Swain, J. Am. Ceram. Soc., 75, 493-502 (1992).

3) W. H. Tuan, R. Z. Chen, T. C. Wang, C. H. Cheng and P. S. Kuo, J. Eur. Ceram. Soc., 22, 2827-2833 (2002).

4) P. G. Rao, M. Iwasa, T. Tanaka, I. Kondoh and T. Inoue, Scripta Mater., 48, 437-441 (2003).

5) D. Sarkar, S. Adak and N. K. Mitra, Compos. Part Appl. Sci. Manuf., 38, 124-131 (2007).

6) L. Gil-Flores, M. D. Salvador, F. L. Penaranda-Foix, A. Fernández, M. Suarez, R. Rosa, P. Veronesi, C. Leonelli and A. Borrell, Ceram. Int., 45, 18059-18064 (2019).

7) Z.-G. Wang, J.-H. Ouyang, Y.-H. Ma, Y.-J. Wang, L.-Y. Xie, Z.-G. Liu, A. Henniche and Y. Wang, Ceram. Int., 45, 14297-14304 (2019).

8) S. Bourban, N. Karapatis, H. Hofmann and W. Kurz, Acta. Mater., 45, 5069-5075 (1997).

9) W. Wang, J. Liu and C. Song, J. Mater. Res., 33, 16811689 (2018).

10) Y. Zheng, H. Li, T. Zhou, J. Zhao and P. Yang, J. Alloy. Compd., 551, 475-480 (2013). 
11) F. Schmid and D. C. Harris, J. Am. Ceram. Soc., 81, 885-893 (1998).

12) J. Wang, H. P. Li and R. Stevens, J. Mater. Sci., 27, 5397-5430 (1992).

13) K. Matsumoto, Y. Itoh and T. Kameda, Sci. Technol. Adv. Mater., 4, 153-158 (2003).

14) H. Ibégazène, S. Alpérine and C. Diot, J. Mater. Sci., 30, 938-951 (1995).

15) K. Seya, B.-K. Jang and S. Ueno, J. Ceram. Soc. Jpn., 123, 433-436 (2015).

16) K. Kamada, K. Hishinuma, S. Kurosawa, A. Yamaji, Y. Shoji, J. Pejchal, Y. Ohashi, Y. Yokota and A. Yoshikawa, J. Rare Earth., 34, 796-801 (2016).

17) A. Ito, Y. You, T. Ichikawa, K. Tsuda and T. Goto, J. Eur. Ceram. Soc., 34, 155-159 (2014).

18) S. Matsumoto, Y. Kaneda and A. Ito, Ceram. Int., 46, 1810-1815 (2020).

19) S. Matsumoto and A. Ito, Opt. Mater. Express, 10, 899$906(2020)$.

20) A. Ito, H. Kadokura, T. Kimura and T. Goto, J. Alloy.
Compd., 489, 469-474 (2010).

21) A. Ramadoss, K. Krishnamoorthy and S. J. Kim, Mater. Lett., 75, 215-217 (2012).

22) H. Toraya, M. Yoshimura and S. Somiya, J. Am. Ceram. Soc., 67, 119-121 (1984).

23) R. N. Patil and E. C. Subbarao, Acta Crystallogr. A, 26, 535-542 (1970).

24) A. K. Deb, P. Chatterjee and S. P. Sen Gupta, J. Appl. Crystallogr., 39, 601-603 (2006).

25) M. W. Pitcher, S. V. Ushakov, A. Navrotsky, B. F. Woodfield, G. Li, J. Boerio-Goates and B. M. Tissue, J. Am. Ceram. Soc., 88, 160-167 (2005).

26) J. Chevalier, L. Gremillard, A. V. Virkar and D. R. Clarke, J. Am. Ceram. Soc., 92, 1901-1920 (2009).

27) O. J. Hunter, R. W. Scheidecker and S. Tojo, Ceramurg. Int., 5, 137-142 (1979).

28) M. H. Park, Y. H. Lee, H. J. Kim, Y. J. Kim, T. Moon, K. D. Kim, J. Müller, A. Kersch, U. Schroeder, T. Mikolajick and C. S. Hwang, Adv. Mater., 27, 18111831 (2015). 